\title{
Budgetary revenue structure at central level of public administration in the federal countries \\ Nataliia REKOVA ${ }^{1}$, Iryna DOLOZINA ${ }^{2}$, Vitalii NITSENKOㅜ, Yurii ZAITSEV ${ }^{4}$, Victor ZAMLYNSKYI ${ }^{5}$
}

\begin{abstract}
Indicators of the central government budgets were analysed in the article with use of calculation of shares of various categories and subcategories of revenues for the purpose of identification of structural features and the directions of structural transformation of budgetary revenue at central level of public administration in the federal countries from 2000 till 2015. The similarity and distinction of structures were revealed during the cluster hierarchical analysis and calculation of the Ryabtsev index. It is proved that there is no unambiguous interrelation between federal type of governance and sources of revenue of central budget. It was also revealed that budgetary revenues in the developed federal states were stabler whereas the most essential structural changes were noted in the countries with emerging economy, and the common phenomenon was distribution of receipts from taxes on income and profit and also taxes on internal operations with goods and services between budgets of various levels and also fixing taxes on the international operations to the central budget. It is found that significantly the tendency to changing in level of fiscal decentralization in federal states is not observed, except for the Russian Federation, in which financial autonomy of regions and local authorities testifies more likely about financial (so - and administrative) centralization.
\end{abstract}

Keywords: budgetary revenues, fiscal policy, central budgets, structure, structural changes, dsitinctions.

JEL: E62, H61, H71, H77

DOI: $10.24818 / \mathrm{amp} / 2018.30-03$

1 Professor PhD, Donetsk National Technical University, Pokrovsk, Ukraine; natarekova@gmail.com

2 Associate Professor, Donetsk National Technical University, Pokrovsk, Ukraine; dolozirina@gmail.com

${ }^{3}$ Associate Professor PhD, Odessa I.I.Mechnikov National University, Odessa, Ukraine; vitaliinitsenko@gmail.com

4 Associate Professor PhD, Kharkiv Petro Vasylenko National Technical University of Agriculture, Kharkiv, Ukraine; zaycev31044@gmail.com,

5 Associate Professor PhD, Odessa National Politechnic University, Odessa, Ukraine; zam.agrariy@gmail.com 


\section{Introduction}

The choice of rational quantitative parameters and qualitative characteristics of the budgetary policy is one of the major government decisions which define the prospects of development of national economies in the long term. The volume of revenues to budgets of various levels as well as financial capacities of governments in the solution of tasks of public administration and ensuring countrie's financial sovereignty depend on revenue structure, types and rates of taxes, an order of tax base calculation, income from state ownership and providing administrative services etc. On the other hand, the level of a tax burden, model of financial behavior, comparative effectiveness of state and municipal property management, an order of distribution of tax and non-tax revenue between budgets of various levels influence health of economic climate, sharpness of political conflicts within the country between the center and territories, define degree of political responsibility of the power to electorate and conscientiousness of tax and budgetary discipline.

The fundamental and complex problematic character of groundation of rational combination of the principles and the purposes, requirements and opportunities, level of fiscal decentralization and neccessity of strengthening control for accumulation and use of financial resources forces both the academic and bureaucratic elite to look for the decision in historical experience and to pay attention to other states' success stories. The specified circumstances encourage drawing closer attention to realization of various national approaches to creation of the budgetary system, first of all its central government level.

\section{Metodological remarks}

\subsection{Literature review}

Questions of effective budgeting remain relevant for scientists always. Among the most important it is necessary to say about comparative researches of budgetary policy's effectiveness and public finance management (Davey K., 2003, Bal-Domanska B., 2002 and 2004, Hallerberg M. et al, 2007, Guess G., Leloup L., 2010, Popesko et al etc.), achievement of a good public finance performance (Khan A. and Hildreth W., 2002, Broadway R. and Shah A., 2007, Lienert I., 2009 etc.), effects of fiscal decentralization and local budgets performance (Schroeder L., 2007, Mikesell J., 2007, Alam M., 2010, Fritz V. et al., 2011, Hedger E. and Lopes A., 2011, Bird R., 2012, Jimenez B., 2014, and others). At the same time most of them are about a case-study whereas the large-scale comparative researches of quantitative parameters of budgets which are of critical importance for finding directions of the budgetary system institutional development remain outside the scietifical interests now.

It is obvious that as the budget is a financial tool of public governance so its quantitative parameters and the budgetary policy content significantly depend on two factors. First of them is the level of state intervention in social and economic processes which, by large, is defined by the volume of the powers taken 
by public institutes. The second one is features of distribution of the powers mentioned above within a power vertical. In terms of law and political sciences it is reflected in forms of governance and primarily in a degree of autonomy of local authorities from central. It is possible to assume with confidence that the difference in quantitative and qualitative features of the budgetary systems in the federal and unitary countries will be noticeable but, and that is more important, the fundamental difference in interpretation of theoretical prerequisites and results of a research of the budgetary systems in these two groups of the countries has to become an initial prerequisite of the analysis. On the other hand, the truth is also that any of institutional or economic forms are not stiffened and changes eventually (Draskovic et al., 2017). It means that in certain situations these differences can be erased.

Thus, the object area of research of the budgetary systems can be divided into several parts: structure and mechanisms of the budgetary system (qualitative aspect) and indicators of budgetary performance (quantitative aspect). Choosing quantitative characteristics of the budget as the general subject of the analysis we face need of the further choice between absolute and structural measures of public finance performance, between a budgetary revenues, expences and interrelation between them, between studying of the object in dynamics or statics.

\subsection{Research objectives and methodology}

Aim of this research is to identificate of structural features and the directions of transformation of structure of budgetary revenue at central level of public administration in the federal states from 2000 till 2015. follow:

For achievement of this aim the following objectives were established as

1) to process statistical material for assessment of structure of budgetary revenue. As a statistical basis of the research data of the IMF on public finance of a number of the federal countries (Austria, Germany, Belgium, Canada, the USA, India, the Russian Federation, Switzerland, Argentina, Brazil, Mexico, Bosnia and Herzegovina, Malaysia) were used. Data on absolute values of revenue of cnetgral government budgets in national currencies were processed that allowed calculation of the corresponding budgets structure indicators in 2000, 2005, 2010, 2015. Fiveyear intervals were chosen randomly, but owing to similarity of electoral cycles of change of governments, and respectively, possible changes of the principles of the budgetary policy, such approach quite allows monitoring of any transformations in structure of budgetary revenue categories. Unfortunately, owing to lack of data, not all selections formed as identical by the size, however their addition with information of national statistics was not done proceeding from need to provide comparability of basic data. It is also necessary to pay attention to the fact that in tables given below the main categories (taxes, grants, other revenue) are not always disclosed in categories of lower order, i.e. basic data are not always classified completely that influences results of assessment of structural changes dynamics. 
2) to analyse dynamics of revenue's structural changes for centreal governments' budgets in federal states. Assessment of economic structure transformation was done with use of the Ryabtsev index (Ryabtsev V., Chudilin G., 2011). Let $\left(s_{1}^{1}, s_{2}^{1}, \ldots s_{n}^{1}\right)$ и $\left(s_{1}^{0}, s_{2}^{0}, \ldots s_{n}^{0}\right)$ are vectors of shares of each analyzed category of revenue in the budget of a certain level respectively during the studied and basic period. Then extent of structural changes can be estimated as:

$$
I_{R}=\sqrt{\frac{\sum_{i=1}^{n}\left(s_{i}^{1}-s_{i}^{0}\right)^{2}}{\sum_{i=1}^{n}\left(s_{i}^{1}+s_{i}^{0}\right)^{2}}}
$$

The choice of the Ryabtsev index among other quadratic indexes (The Gallagher Index, The Monroe index, The Gatev index, The Szalai index, The Aleskerov-Platonov index) was caused by two circumstances - its sensitivity to small selections and existence of a scale of assessment of structural distinctions (tab. 1) that allowed interpreting the received coefficients without use of the comparative analysis.

Table 1. Scale of assessment of structural distinctions by the Ryabtsev index

\begin{tabular}{|c|c|}
\hline Levels & Characteristic of structure similiarity \\
\hline $0.000-0.030$ & Identity of structures \\
\hline $0.031-0.070$ & Very low level of distinction of structures \\
\hline $0.071-0.150$ & Low level of distinction of structures \\
\hline $0.151-0.300$ & Essential level of distinction of structures \\
\hline $0.301-0.500$ & Considerable level of distinction of structures \\
\hline $0.501-0.700$ & Very considerable level of distinctions of \\
& structures \\
\hline $0.701-0.900$ & Opposite type of structures \\
\hline 0.901 and more & Complete antithesis of structures \\
\hline
\end{tabular}

(Source: Ryabtsev V., Chudilin G., 2001)

3) to analyse similarity and distinctions of revenue's structure. As not only categories of budgetary revenue (tax revenues, transfers, own non-tax income) but also their subcategories are of great importance for assessment of distinction of structures, the hierarchical cluster analysis (a method of single-linkage clustering with Euclidean distances) according to the recommendations of Jain A. et al. (1999), Berkhin P. (2006) in a Statistica 10 package was applied to the solution of this task. 


\section{Revenue structures of central government budgets in the federal countries}

Proceeding from the data provided in tab. 2 the main source of revenues of central budgets in the federal countries except for Germany were tax revenues their share in 2000 had $66.3 \%$ of all incomes averaged.

Table 2. Central budgets' structure of revenue in 2000, \%*

\begin{tabular}{|c|c|c|c|c|c|c|c|c|c|c|c|c|c|}
\hline $\begin{array}{l}\text { Categories / } \\
\text { Countries** }\end{array}$ & AUT & BEL & DEU & AUS & CAN & $\mathrm{CHE}$ & USA & IND & MYS & RUS & ARG & BRA & MEX \\
\hline Revenue & 100.0 & 100.0 & 100.0 & 100.0 & 100.0 & 100.0 & 100.0 & 100.0 & 100.0 & 100.0 & 100.0 & 100.0 & 100.0 \\
\hline Taxes & 59.6 & \begin{tabular}{|l|}
64.1 \\
\end{tabular} & $\mid 38.7$ & \begin{tabular}{|l|}
88.9 \\
\end{tabular} & \begin{tabular}{|l|}
71.0 \\
\end{tabular} & 54.6 & 63.0 & 75.0 & \begin{tabular}{|l|}
74.4 \\
\end{tabular} & 55.6 & \begin{tabular}{|l|}
67.9 \\
\end{tabular} & 70.4 & \begin{tabular}{|l|}
79.0 \\
\end{tabular} \\
\hline $\begin{array}{l}\text { on income, profits, } \\
\text { and capital gains }\end{array}$ & 27.7 & 36.8 & 17.1 & 66.7 & 54.4 & 19.9 & 57.5 & 27.0 & 41.0 & 11.5 & 17.0 & 25.1 & $\mid 34.1$ \\
\hline $\begin{array}{l}\text { on payroll and } \\
\text { workforce }\end{array}$ & 3.5 & 0.0 & 0.0 & 2.1 & 0.0 & 0.0 & 0.0 & 0.0 & 0.0 & 0.0 & 0.0 & 1.2 & 0.0 \\
\hline on property & 0.2 & 0.3 & 0.0 & 0.0 & 0.0 & 0.0 & 1.4 & 0.1 & 0.4 & 0.2 & 2.0 & 0.1 & 0.0 \\
\hline $\begin{array}{l}\text { on goods and } \\
\text { services }\end{array}$ & 28.0 & 26.7 & 21.6 & 17.9 & 0.0 & 33.5 & 3.2 & 28.9 & 23.4 & 30.9 & 43.9 & 39.8 & 62.1 \\
\hline $\begin{array}{l}\text { on international } \\
\text { transactions }\end{array}$ & -0.01 & 0.0 & 0.0 & 2.2 & 1.1 & 1.3 & 1.0 & 18.9 & 7.4 & 12.8 & 4.9 & 3.6 & 4.1 \\
\hline other taxes & 0.2 & 0.1 & 0.0 & 0.0 & 0.0 & 0.0 & 0.0 & 0.1 & 2.2 & \begin{tabular}{|l|}
0.1 \\
\end{tabular} & 0.1 & 0.6 & 0.7 \\
\hline Social contributions & 33.4 & 33.4 & 56.9 & 0.0 & 18.9 & 35.7 & 31.3 & 0.1 & 0.0 & 28.8 & 23.4 & 24.8 & 10.5 \\
\hline Grants & 0.5 & 0.4 & 1.1 & 0.1 & 0.3 & 2.5 & 0.0 & 0.3 & 0.0 & 0.5 & 0.0 & 0.0 & 0.0 \\
\hline from foreign govs & 0.0 & 0.1 & 0.0 & 0.0 & 0.0 & 0.0 & 0.0 & 0.3 & 0.0 & 0.5 & 0.0 & 0.0 & 0.0 \\
\hline $\begin{array}{l}\text { from international } \\
\text { organizations }\end{array}$ & 0.3 & 0.0 & 0.1 & 0.0 & 0.0 & 0.0 & 0.0 & 0.0 & 0.0 & 0.0 & 0.0 & 0.0 & 0.0 \\
\hline $\begin{array}{l}\text { from other general } \\
\text { government units }\end{array}$ & 0.2 & 0.2 & 1.0 & 0.1 & 0.0 & 2.5 & 0.0 & 0.0 & 0.0 & 0.0 & 0.0 & 0.0 & 0.0 \\
\hline Other revenue & 6.4 & 2.1 & 3.3 & 11.0 & 9.8 & 7.1 & 5.7 & 24.6 & 25.6 & 15.1 & 8.7 & 4.8 & 10.5 \\
\hline property income & 1.8 & 0.6 & 1.8 & 4.4 & 0.0 & 3.6 & 3.3 & 21.2 & 14.8 & 4.5 & 3.6 & 3.0 & 9.1 \\
\hline $\begin{array}{l}\text { fines, penalties, and } \\
\text { forfeits }\end{array}$ & 0.0 & 0.0 & 0.0 & 0.0 & 0.0 & 0.1 & 0.1 & 0.0 & 0.6 & 0.4 & 0.3 & 0.0 & 0.1 \\
\hline $\begin{array}{l}\text { transfers not } \\
\text { elsewhere classified }\end{array}$ & 1.9 & 0.0 & 0.4 & 2.6 & 0.0 & 0.6 & 1.4 & 0.0 & 3.5 & 10.2 & 0.4 & 0.7 & 0.5 \\
\hline
\end{tabular}

As a part of these receipts the main part was taxes on income, profit and capital gains as well as taxes on operations with goods and services. Only in Russia and India in comparison with other countries receipts from taxes on the international operations were rather more significant (first of all, duties on energy resources in Russia, oil products and diamonds - in India). It is worth noting that in the majority of the countries contributions to social insurance were a significant source of income of budgets (rather in off-budget special funds). The exception in the form of absence of such special funds at the federal level was shown by 
Malaysia and Australia. It should be noted also the fact that membership in the EU meant lack of a national customs tariff in Austria, Belgium and Germany.

Comparison of federal budgets's revenue structure in 2005 (tab. 3) with 2000 data demonstrated some increase in importance of tax revenues and reduction of the importance of non-tax income (over the countries over which there are data both on 2000 and 2005, except Russia). In post-crisis 2010 the average level of tax revenues in federal budgets has decreased all countries till 58.8\%. Its declination in Brazil (-33 percentage points in comparison with 2000) and Mexico (-22.1 percentage points) became the most cardinal (tab. 4).

Table 3. Central budgets' structure of revenue in $2005, \%$

\begin{tabular}{|l|c|c|c|c|c|c|c|c|c|c|c|}
\hline \multicolumn{1}{|c|}{$\begin{array}{c}\text { Categories / } \\
\text { Countries* }\end{array}$} & AUT & BEL & DEU & AUS & CAN & CHE & USA & IND & BIH & RUS & BRA \\
\hline Revenue & 100.0 & 100.0 & 100.0 & 100.0 & 100.0 & 100.0 & 100.0 & 100.0 & 100.0 & 100.0 & 100.0 \\
\hline Taxes & 58.3 & 62.9 & 37.6 & 91.6 & 71.5 & 53.9 & 59.6 & 81.2 & 55.4 & 53.5 & 73.7 \\
\hline $\begin{array}{l}\text { Taxes on income, } \\
\text { profits, and capital } \\
\text { gains }\end{array}$ & 26.9 & 37.2 & 14.8 & 65.2 & 53.1 & 18.4 & 54.3 & 35.9 & 2.0 & 5.7 & 28.4 \\
\hline $\begin{array}{l}\text { Taxes on payroll and } \\
\text { workforce }\end{array}$ & 3.3 & 0.0 & 0.0 & 0.1 & 0.0 & 0.0 & 0.0 & 0.0 & 4.0 & 0.0 & 1.3 \\
\hline Taxes on property & 0.2 & 0.3 & 0.0 & 0.0 & 0.0 & 0.0 & 1.1 & 0.1 & 0.1 & 0.0 & 0.1 \\
\hline $\begin{array}{l}\text { Taxes on goods and } \\
\text { services }\end{array}$ & 27.7 & 25.3 & 22.8 & 24.1 & 0.0 & 34.5 & 3.2 & 30.8 & 22.7 & 23.6 & 41.5 \\
\hline $\begin{array}{l}\text { Taxes on } \\
\text { international trade } \\
\text { and transactions }\end{array}$ & 0.0 & 0.0 & 0.0 & 2.2 & 1.3 & 1.1 & 1.1 & 14.4 & 26.4 & 24.2 & 1.9 \\
\hline Other taxes & 0.2 & 0.1 & 0.0 & 0.0 & 0.0 & 0.0 & 0.0 & 0.0 & 0.3 & 0.0 & 0.5 \\
\hline Social contributions & 32.2 & 34.2 & 58.4 & 0.0 & 21.4 & 36.2 & 36.5 & 0.2 & 33.2 & 17.7 & 23.2 \\
\hline Grants & 0.6 & 0.2 & 1.0 & 0.2 & 0.4 & 3.1 & 0.0 & 0.7 & 1.0 & 2.5 & 0.0 \\
\hline From foreign govs & 0.0 & 0.1 & 0.0 & 0.0 & 0.0 & 0.0 & 0.0 & 0.7 & 0.2 & 0.0 & 0.0 \\
\hline $\begin{array}{l}\text { From international } \\
\text { organizations }\end{array}$ & 0.3 & 0.0 & 0.3 & 0.0 & 0.0 & 0.0 & 0.0 & 0.0 & 0.8 & 0.0 & 0.0 \\
\hline $\begin{array}{l}\text { From other general } \\
\text { government units }\end{array}$ & 0.3 & 0.1 & 0.7 & 0.2 & 0.0 & 3.1 & 0.0 & 0.0 & 0.0 & 2.5 & 0.0 \\
\hline Other revenue & 8.8 & 2.8 & 3.1 & 8.2 & 6.7 & 6.8 & 3.9 & 18.0 & 10.4 & 26.3 & 3.0 \\
\hline Property income & 1.9 & 0.4 & 1.0 & 2.2 & 0.0 & 2.9 & 2.1 & 12.3 & 3.3 & 15.2 & 1.2 \\
\hline $\begin{array}{l}\text { Fines, penalties, and } \\
\text { forfeits }\end{array}$ & 0.0 & 0.0 & 0.0 & 0.0 & 0.0 & 0.2 & 0.0 & 0.0 & 0.5 & 0.0 & 0.2 \\
\hline $\begin{array}{l}\text { Transfers not } \\
\text { elsewhere classified }\end{array}$ & 1.6 & 0.0 & 0.4 & 1.3 & 0.0 & 0.5 & 1.3 & 0.0 & 0.3 & 9.3 & 0.6 \\
\hline
\end{tabular}

* hereinafter: BIH - Bosnia and Herzegovina; Source: calculated on the basis of IMF data (Source: own calculation on the basis of IMF data) 
Budgetary revenue structure at central level of public administration in the federal countries

Table 4. Central budgets' structure of revenue in $2010, \%$

\begin{tabular}{|l|c|c|c|c|c|c|c|c|c|c|c|c|}
\hline \multicolumn{1}{|c|}{$\begin{array}{c}\text { Categories / } \\
\text { Countries }\end{array}$} & AUT & BEL & DEU & AUS & CAN & CHE & USA & IND & BIH & RUS & BRA & MEX \\
\hline Revenue & 100.0 & 100.0 & 100.0 & 100.0 & 100.0 & 100.0 & 100.0 & 100.0 & 100.0 & 100.0 & 100.0 & 100.0 \\
\hline Taxes & 57.8 & 60.6 & 39.6 & 87.9 & 69.3 & 55.8 & 52.2 & 78.6 & 51.1 & 48.9 & 47.4 & 56.9 \\
\hline $\begin{array}{l}\text { on income, } \\
\text { profits, and } \\
\text { capital gains }\end{array}$ & 26.5 & 34.8 & 14.9 & 61.6 & 52.8 & 21.2 & 47.7 & 43.4 & 6.4 & 2.2 & 21.1 & 27.6 \\
\hline $\begin{array}{l}\text { on payroll and } \\
\text { workforce }\end{array}$ & 3.8 & 0.0 & 0.0 & 0.2 & 0.0 & 0.0 & 0.0 & 0.0 & 0.0 & 0.0 & 1.1 & 0.0 \\
\hline on property & 0.1 & 0.4 & 0.0 & 0.0 & 0.0 & 0.0 & 0.6 & 0.1 & 0.1 & 0.0 & 0.0 & 0.0 \\
\hline $\begin{array}{l}\text { on goods and } \\
\text { services }\end{array}$ & 27.2 & 25.4 & 24.6 & 24.3 & 0.0 & 33.6 & 2.8 & 21.7 & 44.9 & 21.1 & 23.1 & 27.2 \\
\hline $\begin{array}{l}\text { on international } \\
\text { transactions }\end{array}$ & 0.0 & 0.0 & 0.0 & 1.9 & 1.2 & 1.0 & 1.2 & 13.5 & 0.0 & 25.6 & 1.9 & 1.1 \\
\hline other taxes & 0.2 & 0.0 & 0.0 & 0.0 & 0.0 & 0.0 & 0.0 & 0.0 & 0.0 & 0.0 & 0.0 & 1.0 \\
\hline $\begin{array}{l}\text { Social } \\
\text { contributions }\end{array}$ & 32.4 & 35.8 & 55.5 & 0.0 & 23.0 & 36.4 & 39.3 & 0.3 & 39.0 & 20.3 & 31.4 & 11.2 \\
\hline Grants & 0.6 & 0.2 & 0.9 & 0.2 & 0.3 & 0.3 & 0.0 & 0.3 & 0.4 & 2.4 & 0.0 & 0.2 \\
\hline from foreign govs & 0.0 & 0.0 & 0.0 & 0.0 & 0.0 & 0.1 & 0.0 & 0.3 & 0.1 & 0.0 & 0.0 & 0.0 \\
\hline $\begin{array}{l}\text { from international } \\
\text { organizations }\end{array}$ & 0.2 & 0.0 & 0.2 & 0.0 & 0.0 & 0.0 & 0.0 & 0.0 & 0.3 & 0.0 & 0.0 & 0.0 \\
\hline $\begin{array}{l}\text { from other } \\
\text { general } \\
\text { government units }\end{array}$ & 0.4 & 0.1 & 0.6 & 0.2 & 0.0 & 0.2 & 0.0 & 0.0 & 0.0 & 2.4 & 0.0 & 0.2 \\
\hline Other revenue & 9.2 & 3.4 & 4.1 & 11.9 & 7.5 & 7.5 & 8.5 & 20.9 & 9.5 & 28.4 & 21.2 & 31.7 \\
\hline $\begin{array}{l}\text { property income } \\
\text { fines, penalties, } \\
\text { and forfeits }\end{array}$ & 1.9 & 0.3 & 1.3 & 4.0 & 0.0 & 2.5 & 5.3 & 6.7 & 2.7 & 15.6 & 18.7 & 27.9 \\
\hline $\begin{array}{l}\text { transfers not } \\
\text { elsewhere } \\
\text { classified }\end{array}$ & 1.8 & 0.0 & 0.3 & 1.8 & 0.0 & 1.6 & 2.0 & 0.0 & 0.9 & 6.3 & 0.7 & 1.0 \\
\hline
\end{tabular}

(Source: own calculation on the basis of IMF data)

Among other important structural changes of 2010 in comparison with previous years it is necessary to pay attention on: 1) further profit of state corporations increase in revenue structure of the Russian, Brasilian and Mexican central budgets, and to a lesser extent - growth in revenue from federal property in the USA; 2) refusal of payroll taxes in Bosnia and Herzegovina; 3) decrease in the importance of taxes on the international operations in all countries.

In 2015 further decrease in a share of tax revenue (tab. 5), even without the United Arabic Emirates which indicator was only 1,2\%, and growth of a share of payments on social insurance were noted. 
Budgetary revenue structure at central level of public administration in the federal countries

Table 5. Central budgets' structure of revenue in 2015, \%

\begin{tabular}{|c|c|c|c|c|c|c|c|c|c|c|c|c|c|}
\hline $\begin{array}{c}\text { Categories / } \\
\text { Countries }\end{array}$ & AUT & BEL & DEU & AUS & CAN & CHE & USA & BIH & RUS & BRA & MEX & ARG & ARE* \\
\hline Revenue & 100.0 & 100.0 & 100.0 & 100.0 & 100.0 & 100.0 & 100.0 & 100.0 & 100.0 & 100.0 & 100.0 & 100.0 & 100.0 \\
\hline Taxes & 59.0 & 60.5 & 40.0 & \begin{tabular}{|l|}
89.8 \\
\end{tabular} & 68.7 & 54.9 & 59.1 & \begin{tabular}{|l|}
51.4 \\
\end{tabular} & 34.5 & 44.5 & 67.2 & 55.7 & 1.2 \\
\hline $\begin{array}{l}\text { on income, } \\
\text { profits, and } \\
\text { capital gains }\end{array}$ & 28.8 & 35.1 & 16.8 & 65.0 & 53.7 & 22.6 & 54.5 & 6.8 & 1.9 & 20.5 & 34.7 & 15.2 & 0.0 \\
\hline $\begin{array}{l}\text { on payroll and } \\
\text { workforce }\end{array}$ & 3.8 & 0.0 & 0.0 & 0.2 & 0.0 & 0.0 & 0.0 & 0.0 & 0.0 & 1.2 & 0.0 & 0.3 & 0.0 \\
\hline on property & 0.1 & 0.6 & 0.0 & 0.0 & 0.0 & 0.0 & 0.6 & 0.1 & 0.0 & 0.1 & 0.0 & 0.6 & 0.0 \\
\hline $\begin{array}{l}\text { on goods and } \\
\text { services }\end{array}$ & 26.3 & 24.8 & 23.2 & 21.9 & 0.0 & 31.4 & 2.9 & 44.3 & 19.4 & 20.4 & 30.2 & 28.0 & 1.0 \\
\hline $\begin{array}{l}\text { on international } \\
\text { transactions }\end{array}$ & 0.0 & 0.0 & 0.0 & 2.7 & 1.5 & 0.9 & 1.1 & 0.0 & 13.2 & 2.3 & 1.3 & 8.0 & 0.2 \\
\hline other taxes & 0.1 & 0.0 & 0.0 & 0.0 & 0.0 & 0.0 & 0.0 & 0.2 & 0.0 & 0.0 & 1.0 & 3.6 & 0.0 \\
\hline $\begin{array}{l}\begin{array}{l}\text { Social } \\
\text { contributions }\end{array} \\
\end{array}$ & 32.3 & 36.4 & 54.6 & 0.0 & 23.7 & 37.8 & 34.2 & \begin{tabular}{|l|}
39.1 \\
\end{tabular} & 21.4 & 31.7 & 11.6 & 31.1 & 6.7 \\
\hline Grants & 0.6 & 0.2 & 0.7 & 0.1 & 0.3 & 0.3 & 0.0 & 0.4 & 20.6 & 0.0 & 0.0 & 0.0 & 27.7 \\
\hline $\begin{array}{l}\text { from foreign } \\
\text { govs }\end{array}$ & 0.0 & 0.0 & 0.0 & 0.0 & 0.0 & 0.1 & 0.0 & 0.4 & 0.0 & 0.0 & 0.0 & 0.0 & 0.0 \\
\hline \begin{tabular}{|l|} 
from \\
international \\
organizations
\end{tabular} & 0.1 & 0.0 & 0.1 & 0.0 & 0.0 & 0.0 & 0.0 & 0.0 & 0.0 & 0.0 & 0.0 & 0.0 & 0.0 \\
\hline $\begin{array}{l}\text { from other } \\
\text { general } \\
\text { government } \\
\text { units } \\
\end{array}$ & 0.4 & 0.1 & 0.7 & 0.1 & 0.0 & 0.2 & 0.0 & 0.0 & 20.6 & 0.0 & 0.0 & 0.0 & 27.7 \\
\hline Other revenue & 8.0 & 2.9 & 4.7 & 10.1 & 7.3 & 7.1 & 6.7 & 9.1 & 23.5 & 23.8 & 21.2 & 13.1 & 64.5 \\
\hline property income & 1.2 & 0.3 & 1.3 & 2.7 & 0.0 & 2.2 & 4.4 & 1.9 & 17.1 & 20.4 & 13.0 & 11.3 & 21.2 \\
\hline $\begin{array}{l}\text { fines, penalties, } \\
\text { and forfeits }\end{array}$ & 0.0 & 0.0 & 0.1 & 0.0 & 0.0 & 0.4 & 0.0 & 0.6 & 1.3 & 1.2 & 0.3 & 0.1 & 1.9 \\
\hline $\begin{array}{l}\text { transfers not } \\
\text { elsewhere } \\
\text { classified }\end{array}$ & 1.7 & 0.0 & 0.3 & 1.6 & 0.0 & 1.3 & 1.7 & 2.1 & 1.5 & 1.4 & 5.3 & 0.0 & 4.8 \\
\hline
\end{tabular}

In a section of the countries it should be noted reduction of the importance of receipts from taxes on internal operations with goods and services and increase from taxes on external operations in Argentina.

More detailed joint analysis of these tables and fig. 1a allows to allocate the following groups of the countries on similarity of budgetary revenue structure at the level of central government in 2000. 


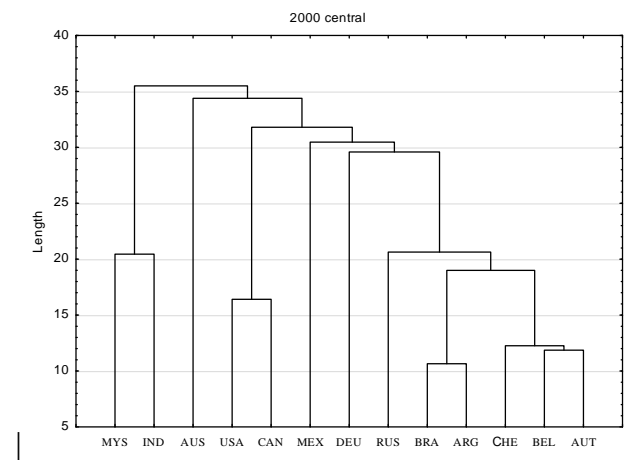

a)

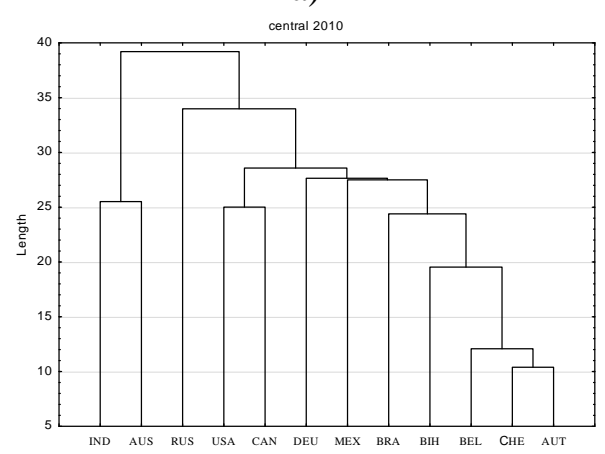

c)

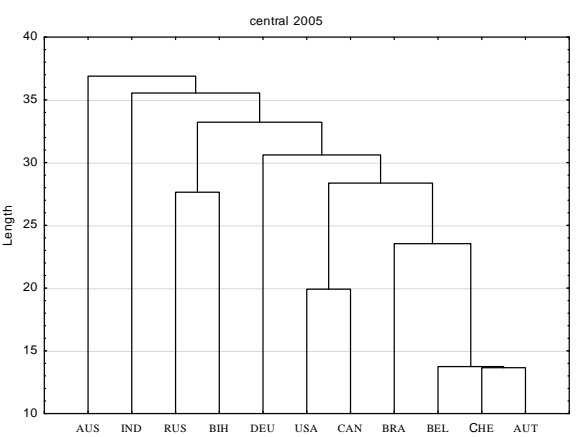

b)

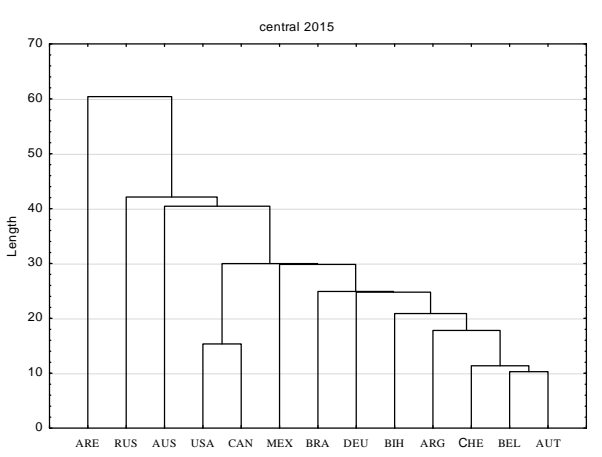

d)

Figure 1. Clusters of countries by central budgets' structure of revenue in: a) 2000 ; b) 2005 ; c) 2010 ; d) 2015 .

(Source: own researches

The first group contained countries in which tax revenues made 3/4 budget revenues of the central government, and taxes on income and profit and taxes on operations with goods and services were the main subcategory of tax revenues in the central budget (India and Malaysia). Distinctive feature of this group is the fact that remained 1/4 of income were own non-tax receipts, first of all, from use of federal property.

The second group is more non-uniform and it is possible to allocate several subgroups of lower order within it. Specific characteristics of formation of federal revenues of Australia were as following: the share of tax revenues was the highest (nearly 90\%) of the analyzed countries; $2 / 3$ of them were taxes on income of natural persons and profit of corporations; besides, as already it has been noted above, in Australia function of social security was not assigned to the federal government.

Approximately identical shares of the main budget revenues can be considered as a similar line of two countries wich were in the next group (the USA and Canada): level of tax revenues (60-70\%), from which more than a half was the share of taxes on income and the capital, low value of own non-tax receipts (up to 
$10 \%)$ and lack of reverse grants from budgets of states and local budgets to federal. Feature of formation of revenues in Mexico's federal budget was high (about 80\%) share of tax revenues which, unlike other countries, was fomed by taxes on commercial operations with goods and services $(62.1 \%$ of all federal revenues of Mexico in 2000) and also the importance of social contributions and income from federal property for formation of cumulative financial resources of the central government. As for Germany, in 2000 it was the only federal country in which the share of tax revenue of the federal budget was less than $50 \%$ while the main part of receipts were obligatory contributions for social insurance (57\%). In structure of revenues of Russian federal budget in 2000 the share of taxes on income and profit was the lowest on selection (11.5\%) at rather lower share of tax component in incomes in comparison with other countries. The most part of tax revenues was formed by reciepts of taxes on a trade turnover and excise taxes. Traditionally (for the countries of the former USSR) the central government bears a burden of social security that caused the high importance of social contributions (28.8\%). Structure of revenues of federal budgets of Brazil and Argentina were in many respects similar to the Russian. The main differences consisted in lower importance of state ownership and smaller importance of taxes on the international operations in generation of federal revenues. Common features of formation of federal budget's revenues in Belgium, Austria and Switzerland were following: level of tax revenues is $55-65 \%$ and the main part from which are taxes on operations with goods and services; a high share of social payments in the cumulative federal budget at the low importance of income from property and providing administrative services.

Though there were some changes in grouping of the countries in 20052015 in comparison with 2000 (fig. 1 b-d), but they generally were not connected with cardinal transformations in mechanisms of the budgetary policies. In 2010 in Australia and India the highest levels of tax income in structure of financial resources of federal budgets were noted (according 91.6\% and 81.2\%) though it is necessary to pay attention that India had shown growth in 6.2 percentage points which was a consequence of economic growth whereas change of a share of this subcategory in Australia ( +2.7 percentage points) rather had random character. There were Russia and Bosnia and Herzegovina in group of the countries in which a budget forming role both taxes on goods and services and on the international operations played in 2010. At the same time the dependence from state corporations (first of all, Gazprom) in formation of the budget strengthened in Russia (the share of own non-tax receipts has made 26.3\%). In a complex the specified circumstances caused some rearrangement of cluster structure of the countries (fig. 1c) though as well as in 2005 it is impossible to concern it as cardinal. Analyzing data of 2015 (fig. 1d) it should be noted that difference degree between the countries decreased in group 2 (in terms of 2000), however due to specifics of the United Arabic Emirates and the Russian Federation the scale of distances between the main clusters grew in general (in 2000-2010 the level of Euclidean distance did not exceed 40 whereas in 2015 it equaled to 60). 
Dominating part of federal revenues in the United Arabic Emirates was occupied by own non-tax receipts, including those in the form of fund of the sovereign wealth created of the assignments from profit on oil sales. Besides, regarding tax revenues the federal budget was formed only by taxes on internal and international operations with goods and services. In Russia the form of accumulation of wealth from export of energy resources differs from the United Arabic Emirates a little - it is the profit of the state corporations in the fuel sector, however sharp growth (from $2.4 \%$ to $20.6 \%$ ) of reverse grants became essential change in revenue structure of the Russian federal budget in 2015.

As for a question of assessment of dynamics of structural transformations (tab. 6), proceeding from the actual values of the index of Ryabtsev the revenue structures of federal budgets changed in the most way in the Russian Federation, Argentina, Brazil and Mexico, i.e. the countries with emerging economies which were very sensitive to external shocks and internal contradictions.

Table 6. Ryabtsev indexes of change of central budgets' revenue structure

\begin{tabular}{|l|c|c|c|c|}
\hline \multicolumn{1}{|c|}{ Countries } & $\mathbf{2 0 0 5} / \mathbf{2 0 0 0}$ & $\mathbf{2 0 1 0} / \mathbf{2 0 0 5}$ & $\mathbf{2 0 1 5} / \mathbf{2 0 1 0}$ & $\mathbf{2 0 1 5 / 2 0 0 0}$ \\
\hline Austria & 0,025 & 0,008 & 0,000 & 0,027 \\
\hline Belgium & 0,013 & 0,023 & 0,006 & 0,032 \\
\hline Germany & 0,023 & 0,028 & 0,018 & 0,025 \\
\hline Australia & 0,041 & 0,030 & 0,024 & 0,031 \\
\hline Canada & 0,023 & 0,016 & 0,007 & 0,033 \\
\hline Switzerland & 0,017 & 0,041 & 0,021 & 0,040 \\
\hline USA & 0,042 & 0,071 & 0,066 & 0,040 \\
\hline India & 0,099 & 0,090 & - & $0,131 *$ \\
\hline Russian Federation & 0,193 & 0,062 & 0,280 & 0,375 \\
\hline Argentina & - & - & - & 0,916 \\
\hline Brazil & 0,034 & 0,279 & 0,047 & 0,297 \\
\hline Mexico & - & - & 0,157 & 0,200 \\
\hline Bosnia and Herzegovina & - & 0,239 & 0,015 & $0,238 * *$ \\
\hline
\end{tabular}

Important structural changes in comparison with previous years happened in formation of revenues of federal budgets in Mexico (the share of taxes on internal operations with goods with services decreased by 31.9 percentage points and the importance of own non-tax federal revenues increased at the same time), Argentina (the share of tax income leveled down by 12.2 percentage points, the share of taxes on goods and services - by 15.9, revenues for nation-wide social security grew by 7.7 percentage points) and Brazil (reduction of a tax revenues share by 25.9 percentage points against the background of the simultaneous growth of own non-tax revenues share by 19.0 percentage points as well as revenues for obligatory state insurance - by 6.9 percentage points). 


\section{Conclusions} conclusions:

Generalizing the received results, it is necessary to draw a number of

1) the received vectors of revenues structures of the central government budgets in the federal countries show lack of unambiguous interrelation between type of state system and sources of income of budgets;

2) the budgetary revenue structures in the developed federal states are stabler whereas the most essential structural changes are noted in the countries with emerging economies;

3 ) the common phenomenon is distribution of receipts from taxes on income and profits and taxes on internal operations with goods and services between budgets of various levels and also fixing of a several taxes to budgets of certain levels (taxes on the international operations - the central budget, the property taxes - regional and local budgets);

4) the significant tendency to increase in level of fiscal decentralization in federal states was not observed, except for the Russian Federation, in which financial autonomy of regions and local authorities testifies more likely about financial (as well as administrative) centralization;

At the end it is critical to accent that the accuracy of the received results in essential measure depends on completeness and structurization of basic data that raises requirements to formation of government financial statistics internationally. It will also be expedient to develop the studied issue in line with a research of compliance between quantitative indices of budgets and features of institutional structure of the budgetary system in each of the analyzed countries.

\section{References}

Alam, M. (ed). (2010). Municipal infrastructure financing. Innovative practices from developing countries. Commonwealth Secretariat Local Government Reform Series No. 2. Retrieved from: https://searchworks.stanford. edu/view/10376867

Bal-Domanska, B. (2002). Application of Mahalanobis Distance in the Analysis of the Structure of Budgetary Revenue of Counties. [In Polish]. Prace Naukowe Akademii Ekonomicznej we Wroctawiu, 950, pp. 52-60

Bal-Domanska, B. (2004). Classification of Counties by Budgetary Revenue Levels and Structure. [In Polish]. Prace Naukowe Akademii Ekonomicznej we Wrocławiu, 1023, pp. 324-331.

Berkhin, P. (2006). A survey of clustering data mining techniques: Jacob Kogan, Charles Nicholas, and Marc Teboulleeds. Grouping Multidimensional Data: Recent Advances in Clustering, pp. 25-71, Springer.

Bird, R.M. (2012). Subnational taxation in large emerging countries: BRIC plus one. Institute on Municipal Finance and Governance Paper on Municipal Finance and Governance, 6. Munk School of Global Affairs. IMFG, 
Toronto. Retrieved from: https://munkschool.utoronto.ca/imfg/uploads/ 185/bird_imfg_no._6_r5_online.pdf

Broadway, R. \& Shah, A.(2007). Intergovernmental Fiscal Transfers: Principles and Practice. Washington, DC: World Bank. Retrieved from: http://siteresources.worldbank.org/PSGLP/Resources/IntergovernmentalFis calTransfer s.pdf

Draskovic, M., Milica, D., Mladen, I., \& Chigisheva, O. (2017). Preference of institutional changes in social and economic development. Journal of International Studies, 10(2), pp. 318-328.

Khan, A. \& Hildreth, W. B. (ed.). (2002). Budget theory in the public sector. Westport, Connecticut, London, Quorum books.

Davey, K. (Ed). (2003). Fiscal Autonomy and Efficiency: Reforms in the Former Soviet Union (Lgi Fellowship Studies). Budapest, Open Society Institute.

Fritz, V., Hedger, E. \& Lopes, A. (2011). Strengthening Public Financial Management in Postconflict Countries. Washington, DC: World Bank. Retrieved from: http://siteresources.worldbank.org/INTPREMNET/ Resources/EP54.pdf

Guess, G.M. \& Leloup, L,T. (2010). Comparative public budgeting. Albany, NY University of New York Press.

Hallerberg, M., Strauch, R., \& Von Hagen, J. (2007). The design of fiscal rules and forms of governance in European Union countries. European Journal of Political Economy, 23 (2), pp. 338-359. DOI: http://dx.doi.org/10.1016/ j.ejpoleco.2006.11.005.

International Monetary Fund Government Finance Statistics (GFS). Retrieved from: http://data.imf.org/?sk=FA66D646-6438-4A65-85E5-C6C4116C44 16

Jain, A., Murty M. N. \& Flynn, P. (1999). Data clustering: A review.ACM Computing Surveys 31(3), pp. 264-323.

Jimenez, B. S. (2014). The Fiscal Performance of Overlapping Local Governments. Public Finance Review, 43(5), pp. 606-635. https://doi.org/10.1177/ 1091142114535836

Lienert, I. (2009). Modernizing Cash Management. Technical Notes and Manuals. Washington, DC: IMF. Retrieved from: http://blog-pfm.imf.org/ pfmblog/fad-technical-notes-and-manuals-on-public-financial management .html.

Mikesell, J.L. (2007). Fiscal administration in local government: an overview: Shah, A. (ed.) Local budgeting, public sector governance and accountability series, pp. 15-51. The World Bank, Washington, DC.

OECD (2009). Government at a Glance 2009, OECD Publishing, Paris. http://dx.doi.org/10.1787/9789264075061-en.

Popesko, B., Kljucnikov, A., Hrabec, D., \& Dokulil, J. (2016). Predictability of Business Environment within Budgeting Process-is it Connected with Fluctuations of Economy?. Economics \& Sociology, 9(2), pp. 90-100.

Rodden, E., Eskeland, G.S. \&Litvack, J. (eds). (2003). Fiscal decentralization and the challenge of hard budget constraint. The MIT Press, Cambridge 
Ryabtsev, V. M. \& Chudilin, G. I. (2001). Regional statistics [In Russian]. Moscow, MID.

Schroeder, L. (2007). Forecasting local revenue and expenditures: Shah, A. (ed.) Local budgeting. Public sector governance and accountability series, pp. 53-77. The World Bank, Washington, DC.

Von Hagen, J. (2006). Fiscal rules and fiscal performance in the European Union and Japan. Monetary and Economic Studies, Institute for Monetary and Economic Studies, Bank of Japan, 24(1), pp. 25-60. 